\title{
Commercial Practices In The Ancient Indian Peninsula: Glimpses From Kautilya's Arthashastra
}

\author{
Monsurur Rahman, Indiana University of Pennsylvania, USA \\ Framarz Byramjee, Indiana University of Pennsylvania, USA \\ Reza Karim, Karim and Associates, USA
}

\begin{abstract}
Very few westerners ever heard of Chanakya, a.k.a Kautilya. Kautilya is credited with compiling the treatise on statecraft called the "Arthashastra." This treatise contains fifteen distinct chapters or parts encompassing all components of statesmanship that a ruler needs to run the affairs of his kingdom. This paper briefly narrates some of the commercial practices prevalent in Ancient India enumerated in Kautilya's Arthashastra during the Mauryan period.
\end{abstract}

Keywords: Commercial; Trading; Wholesale; Export/Import; Retailing

\section{INTRODUCTION}

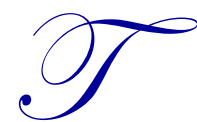

he Arthashastra is a comprehensive treatise covering virtually all aspects of human life. Artha means wealth and Shashtra means science; thus Arthashastra literally implies the science of acquiring and managing wealth. Arthashastra was conceived and named as the Science of Wealth. It focused on creation of wealth as the means to ensure the well being of the state (Raghvan, 1998). The treatise comprises a cohesive whole, including economic administration of the state, trading, imports/exports, retailing, transportation, warehousing, taxation, and consumer welfare. A significant part of the Arthashastra deals with the science of wealth or economics. When it deals with politics, the Arthashastra describes in detail the art of government in its widest sense - the maintenance of law and order of efficient administrative machinery (Rangarajan, 1987).

Kautilya was a great proponent of the notion that the state or government has a crucial role to play in maintaining the material well-being of the people in a nation. Arthshastra focused on preservation of the state through alliances. Arthashastra viewed good counsel and fair judgment as the constituents of the state's power and as more useful than military might. Arthashastra takes a managerial perspective on managing the affairs of the state (Raghvan, 1998). A perfect balance had to be maintained between state management and people's welfare, and this was the essence of Kautilya's economic treatise, Arthashastra, created about 2,300 years ago.

The next section of the paper gives a brief historical background behind the compilation of Arthashastra. Arthasastra contains virtually all aspects of commercial transactions in excruciating detail. The remainder of the paper then describes how these functions were performed in Ancient India during the Mauryan period.

\section{HISTORICAL BACKGROUND}

Part myth, part legend, and part history, Kautilya was believed to be the person instrumental in creating the Mauryan dynasty. He served as teacher, mentor, and chief minister of the Mauryan ruler, Chandragupta Maurya. Chandragupta was contemporary of Alexander, the Macedonian conquistador who, history recalls, conquered much of the then known civilized world. Alexander died around 323 BC and Chandragupta Maurya established his kingdom around that time. Some Greek historical records suggest that he may have visited Alexander in 326 BC.

Not much is known about the early life of Kautilya, but the legend says that his father belonged to the Kautilya Gotra (clan); hence he is called Kautilya. History suggests his given name was Vishnu Gupta. To make 
things more confusing and, at the same time, interesting for the historians, he was also known as Chanakya since he was born in the village of Chanak. The diplomatic quarters in the capital city of modern India, New Delhi, is named Chanakyapuri in honor of Chanakya.

Before becoming the chief minister of Chandragupta Maurya, Kautilya was a professor at Takshashila University. The seat of the Mauryan empire was located in Patna, Bihar province of India. University professors at that time were polyhistors who used to teach a variety of subjects, mostly to princely class. Kautilya mentored Chandragupta Maurya in the diverse fields of knowledge that he would eventually need to establish his kingdom. Interested readers may consult the references at the end of the paper to know more about his life and work.

\section{The Kautilyan Economy}

The Arthashastra divides the economy of the state into three basic types of activities - agriculture, cattle rearing, and trade. The state accumulated wealth by generating resources in the form of grains, cattle, gold, forest produce, trade, and labor. Kautilya created a centralized administration for the newly created empire. Because the regime was authoritarian in nature, everything was organized in the interest of the state. An elaborate civil service existed and there were departments for accounts, revenue, mines, arsenals, taxation, agriculture, trade, and navigation (Edwardes, 1961). Besides maintaining the existing productivity in forests, factories, mines, and cattle herds, the King was also responsible for promoting trade and commerce by setting up market towns, ports, and trade routes, building storage reservoirs (Rangarajan, 1987).

The whole economic policy was regulated and controlled by the state. It was the largest employer of labor. All industrial and natural resources were owned by the state. The state also entered the market as a trader. It engaged in selling activities at the marketplace. It had its own superintendent of commerce who would supervise the dealings in the market, and the revenues earned by sale of resources owned by the state would be directed to the treasury. Thus, trade benefited by adding wealth to the state. The principle of modern mixed economy can be traced back to Kautilya's times (Mukherjee, 1976).

Establishment of the vast empire acted as a stimulus to production and exchange (Shastri, 1957). Weavers and other handicraftsmen, braziers, oil-millers, bamboo-workers, corn-dealers, and artisans fabricating hydraulic engines started organizing themselves into economic corporations known as guilds, which often served the purpose of modern banks (Thapar, 2003).

\section{Principles of Trading}

Trade was a controlled process in Ancient India. Commodities and products (of the countryside) could not be sold in the places of their production but were sold only at designated markets or brought into the city and sold after payment of a duty. The sale of all commodities belonging to the crown (produced on crown property or received into the treasury) was centralized; i.e., conducted only at a specific location - generally the center square in the marketplace of the city. The officers in charge of sale of these crown commodities would deposit the proceeds in a wooden box; and at the end of each day of sale, they would hand over the money box, the balance stocks, and their weighing and measuring instruments.

Certain merchants were also authorized by the state to sell commodities in the marketplace at prices fixed by the chief controller of state trading. When commodities existed in excess supply, the chief controller of state trading would have the authority to build up buffer stock by paying a price higher than the market price. When the market price would reach the support level, he would adjust the price according to the situation. Prices could be fixed taking into account the investment, the quantity to be delivered, duty, interest, rent, and other expenses. The chief controller of state trading would ascertain the profitability of a trading operation with a foreign country, in order to allow exports of commodities and sales abroad. The price of goods to be sold and the gains thereof would be estimated and weighed against those obtained through domestic trade in order to sanction the exports (Rangarajan, 1987).

The state provided encouragement to traders dealing in the sale of imported goods. Merchants - foreign and domestic - who brought in foreign goods by caravans or by water route, enjoyed such incentives as exemption from 
taxes and higher profit margins, and immunity from lawsuits (so as to make profits). The profit margins allowed to merchants would be on the order of five percent for locally produced goods and ten percent for imported goods. Import and sale of foreign goods was encouraged in order to make them freely available through state-approved channels all over the country (Rangarajan, 1987).

Trade - both foreign and domestic - was encouraged as it constituted a considerable portion of the state revenues (Thapar, 2003). Trade was partly in the hands of officials and partly in those of shopkeepers or traveling merchants (Shastri, 1957). The Arthashastra prescribed that profits be shared equally among workmen who labored together toward a common goal. However, proportionality in sharing of earnings would be applied when division of labor existed (Kollam, 2001). So, officials and employees who shouldered higher responsibilities were entitled to higher earnings in proportion with their status and work patterns.

Private enterprises were allowed to run side by side with state-controlled traders; however, private traders were looked upon with suspicion by the people and were taxed and fined severely by the state if indicted with malpractice (Mukherjee, 1976). Their propensity to fix prices by forming cartels, make excessive profits or deal in stolen property, was guarded against by making these offences punishable by law. Kautilya emphasized honesty and justice in trading. He recommended heavy fines for traders who would collude and fleece buyers by conspiring together to hold back wares and later sell them at higher prices (Irani \& Silver, 1995). The Chief Controller of Private Trading kept a watch over merchants, by periodically inspecting their weights and measures and ensuring that they did not hoard merchandise, adulterate foods, or add excessive mark-ups (Rangarajan, 1987). Trust and confidence in the measurement system; i.e., the weights and measures, and also protection against counterfeiting of coinage, was necessary to ensure the state's integrity of commerce (Birch, 2001).

\section{Imports/Exports Activities}

International trade has always been an essential element of commerce during Ancient India. Its border was accessible through several routes which were paved for trading commodities. Commercial activities for import/export purpose required establishing contacts with foreign traders for shipping/receiving goods via these trade routes. The state employed officers who traveled to foreign lands as its dignitaries. They studied the buying and selling activities and consumption patterns of merchants and customers in foreign markets and recognized potential markets for sale of indigenous goods. Commerce relations were built with diplomats from overseas for exchanges of commodities. The Mauryan government built ships and let them out on hire for transport of merchandise (Thapar, 2003). Traders had to pledge their assets - like their homes or lands - as collateral when hiring ships for transporting their goods. The fair value of the goods being shipped into or out of the country was quoted by the state (customs officers) and the merchants were assessed the hiring fee which was to be paid upon return of the vessels.

Goods traded were classified into three kinds: 1) those produced in the countryside, 2) those produced in the city, and 3) those imported from other countries. All three types of goods were subject to payment of customs duty whenever they were imported (into the city) and/or exported (from it). The frontier office had the vested authority to inspect the caravans carrying foreign goods and classify the goods as those of high value or low value based on nature of the products and the value quoted for each of them by their respective merchants. The packages would be sealed with the official seal and identity papers issued to the merchants, along with the appropriate cess (i.e., the duty levied upon the goods in that consignment).

All details about the caravans and their associated consignments would then be communicated to the Chief Collector of Customs. On arrival at the city gates, the collector and his office would inspect the caravans and make his appraisal on the basis of information received from frontier officers or spies of the king. Some goods were exempt from duties, mostly for religious ceremonies or goods meant as wedding gifts. All dutiable goods would be weighed, measured or counted, and the duty payable on them would be collected at the ports of entry. Penalties would be levied on violators who tried to cheat or escape payment (Rangarajan, 1987).

This system of inspecting goods twice was enforced in order to ensure that merchants did not sell their products at any locations other than the marketplace, which was the sole center designated by the state for buying 
and selling of goods. Also, sale at the marketplace alone would ensure that merchants did not make excess profits, as they would be continually subject to scrutiny by the law. After payment of duty, a merchant would typically enter the marketplace. He would place himself near the customs house and declare the type, quantity, and price of his goods. He would call out for bids three times and sell to anyone who was willing to buy his products at the price demanded. If there was competition among buyers and a higher price was realized, the difference between the call price and the sale price, along with the duty thereon, would go to the treasury (Rangarajan, 1987).

\section{Wholesale Trade and Retailing}

Retailers played a significant role in trading activities. An agent selling goods on behalf of another party was paid on a commission basis. Increased sales, with higher profits, meant more commission for the agent, which served as an incentive for him to market the products better and sell more of them. If the price realized was lower because of missing the best opportunity for sale, the agent would pay the owner the cost of the goods at the time he received them and the normal profit. Whenever no profit was made, the retail seller would pay, to the wholesaler or the owner of the commodities, only the price of the goods. If the price fell between the time of entrusting the goods and the time of sale, only the lower price actually realized would be payable. In case of goods sold abroad and those sold after a lapse of time, the amount payable would be reduced by the expenses and losses, if any (Rangarajan, 1987).

This pattern of business shows that there were wholesalers, retailers, and direct marketers in their trade channel. Goods which were sold by the producers themselves in the marketplace exhibit a pattern of direct marketing. Agents played the role of retailers selling goods in the market without assuming title of the goods. Merchants, who bought goods from indigenous/foreign manufacturers and transported them in caravans and ships to the marketplace, sold these goods in the market at the fair price and pocketed the earnings. This is very similar to modern marketing channels of distribution where wholesalers assume title and ownership of goods from their producers and then sell these goods in the market at their price. Brokers and middlemen did play their role too in trade, even in those days; however, they were always looked upon with skepticism and hence the controller was to watch over their activities. These brokers played only the role of intermediaries for passage and sale of goods in the open market but never claimed title or ownership of the goods that they were to sell on behalf of the producers, much like the way it is done today.

\section{Role of Warehousing and Transportation}

The Chief Superintendent of Warehouses was in charge of granaries and warehouses for fats and oils, sugar and honey, salt, vinegars, fruit juices, sour liquids, spices, dried fish, dried meat and vegetables, and cotton and flax. These were basic items and amenities necessary for survival of the population; hence, their preservation was imperative for the state. The superintendent would keep an account of all commodities received into the warehouses and duly classify the inventory held in there as revenue received from taxes, exchanges on barter basis, borrowings, aid, labor, gifts to the king, surcharges, or miscellaneous receipts (Rangarajan, 1987). During the Maurya period, villages were encouraged to have their own grain reserves which would serve as buffers during famine and the kings also maintained their own emergency stocks (Bhatia, 1970).

Prior to this era, items would be manufactured close to the sources of raw material and artisans would congregate from surrounding areas. As trade routes widened during the Mauryan period, development of roadways for inter-regional exchange activities of commodities started cropping up. With interconnections of roadways and sea-routes, there was a greater dispersal of craftsmen, with many gathering in centers where there were markets. Exchange of goods of various trades, from food and clothing to metals and mining, was facilitated over long distances (Majumdar, Raychaudhuri, \& Datta, 1967).

Transportation of goods and commodities by sea and land was an essential function of the state. The Chief Controller of Shipping and Ferries had a wide range of responsibilities - supervising maritime safety and rescue, running shipping services, hiring ships and boats with or without crew, organizing ferries, controlling the movement of foreign merchants, collecting revenue such as road cess, customs duty, and ferry charges, and ensuring security by keeping a watch over undesirable persons using the ferries. 
The Chief Controller of State Trading was conversant with the details, pertaining to all state monopoly commodities (whether imported or produced locally), such as the state of public demand, price fluctuations, relative prices of high and low value goods, and the optimum time for buying, selling, stocking, and disposal (Rangarajan, 1987). Several merchants and traders were also involved in transporting commodities via caravans and ships. A toll had to be paid on the movement of merchandise from one place to another (Edwardes, 1961).

\section{CONCLUSION}

This paper briefly discussed different commercial activities that used to take place during the Mauryan period in Ancient India. This discourse reflects on how trade and commerce of the civilizations has always played a vital role as an integral part in the daily interaction of its citizens. The terminologies employed may have evolved, but the nature of the transactional and relational components of exchange, and their role in trade and commerce seem consistently pertinent over time.

\section{AUTHOR INFORMATION}

Monsurur Rahman, DBA, CPA, CMA, is a Professor of Accounting at Indiana University of Pennsylvania. He received his doctorate from Southern Illinois University-Carbondale. His research has been published in The National Accounting Journal, Southwest Business and Economics Journal, and Journal of Accounting and Finance Research as well as many national regional conference proceedings. His research interests are in the area of Financial and Managerial accounting. E-mail: mrahman@iup.edu

Framarz Byramjee is an Associate Professor of Marketing at Indiana University of Pennsylvania, USA. He has a $\mathrm{Ph} . D$. in Business Administration from Florida Atlantic University, along with a master's degree in systemsengineering/business and an engineering degree. He has industrial work experience in various fields of engineering and business. His teaching and research activities pertain to marketing strategy and analysis, marketing research, business logistics, and operations. E-mail: byramjee@iup.edu (Corresponding author)

Reza Karim is a Management Consultant based in Haslett, Michigan. He received his doctorate from SUNYAlbany. He has extensive teaching and research experience. His current research and consulting service is in the areas of strategy, organizational theory, and supply chain management. E-mail: rkarim@att.net

\section{REFERENCES}

1. Bhatia, P. (1970). Historical perspective of food management in India. Indian Households: Food and Nutrition Security, India.

2. Birch, J. A. M. (2001). Benefits of legal metrology for economy and society. Hunter's Hill, Australia: CIML.

3. Edwardes, M. (1961). A history of India - From the Earliest times to the present day.

4. Irani, K. D., \& Silver, M. (1995). Social justice in the ancient world. Westport, Connecticut: Greenwood Press.

5. Kollam (2001). Psychology in India: Past, present and future. Infinity Foundation, NJ.

6. Majumdar, R. C., Raychaudhuri, H. C., \& Datta, K. (1967). An advanced history of India. New York: St. Martin's Press.

7. Mukherjee, B. (1976). Kautilya's concept of diplomacy. Calcutta, India: Minerva Associates Publications Pvt. Ltd.

8. Raghvan, V. R. (1998). Arthashastra and Sunzi Bingfa - Across the Himalayan gap. New Delhi, India: Gyan Publishing House.

9. Rangarajan, L. N. (1987). Kautilya - The Arthashastra. Penguin Books India Ltd.

10. Sastri, N. K. A. (1957). A comprehensive history of India - Volume two: The Mauryas and Satavahanas. Orient Longmans, India.

11. Thapar, R. (2003). Early India - From the origins to AD 1300. Berkeley and Los Angeles, CA: University of California Press. 
NOTES 